\title{
An Assertive Method as Help in Catechesis?
}

\begin{abstract}
The problem of discipline, and motivation in the learning process, is ever more glaring in catechesis. The assertive approach attempts to, at least partially, solve this problem in modern education. This discussion will show that it is possible to use this approach if assertiveness is enriched by the fundamental anthropological discovery as developed by P. Ricoeur in his hermeneutics of selfhood. He does not see human personality as static, but as dynamic, which gives key roles to three forms of passivity: towards one's own body, towards others, and towards one's conscience. The concept of passivity will be woven into catechesis, which aligns better to the spirit of Christian theology. The example of Jesus' catechesis on the road to Emmaus will be used to show the practical usefulness of assertiveness, and the triple passivity in Christian evangelization.
\end{abstract}

\section{Keywords}

Assertive method, catechesis, P. Ricoeur, passivity, God's pedagogy, selfhood.

\section{Introduction}

Many of today's teachers find it difficult to adapt to order and discipline which are necessary for the successful implementation of the learning process in a classroom. The problem is not just with individual students, who are unable to accept certain standards of behavior necessary for successful pedagogical work, but also in the attitude that society has towards listening, obedience, and following directions. Many people claim that the problems with discipline are primarily a pedagogic concept. According to them, children are not meant to 
sit and listen, but to actively and creatively spend their time. ${ }^{1}$ We can certainly overcome some disciplinary problems with a more hands-on learning approach. But even in those models, sooner or later the student will have to be willing to perform a task he or she might not like, and follow certain directions.

Aside from disciplinary struggles of modern education, attention is increasingly paid to the alienation of students from the teacher and fellow students. Individualism is no longer seen only as the ability to stand up for oneself, and to live in a society while maintaining one's own personality. Nowadays, as noticed primarily by teachers, individualism means not caring about others. Children, in their nature, are able to sense others: we are born with empathy. But in the process of growing up today, this inborn sense is getting lost. This insensitivity to others decreases our ability to see and hear others, and inhibits our willingness to consider their interests. In order to learn, it is imperative to be open to things other than ourselves, our view of life, and our needs. Teachers, as well as schoolmates, are the only ones who can present new ideas to a student, who for the first time in his or her life enters a very formal society. Without the openness to others, it will be difficult for us to learn anything.

When we look at religious education, things get even more difficult. Christian education must be founded on Revelation. This does not mean to blindly follow, but certainly to be open to the message. ${ }^{2}$ If this is missing, catechesis will be very difficult. It is becoming increasingly difficult to speak to the youth in such a way that they receive the message, mostly because they do not even listen to it. We often assume that they are distracted by the noise of our modern environment, which is true to some extent. Another reason why even adults are unwilling to listen to the message, is the love of self, which is supposedly a consequence of the modernity and its legacy. ${ }^{3}$ The emergence of modern religious practices, in which everyone seeks only their own pleasure, and where we see a marketplace of beliefs, from which people choose what they want, is a proof that modernist truth seeking is still prevalent. If we want to prepare people for the Revelation, we must prepare them to be capable of listening to God's call.

${ }^{1}$ See L. Lantieri ed., Schools with Spirit. Nurturing the Inner Lives of Children and Teachers, Boston 2001, Beacon Press, p. 37.

${ }^{2}$ See R. R. Topping, Revelation, scripture and church: theological hermeneutic thought of James Barr, Paul Ricoeur and Hans Frei, Burlington, Aldershot 2007, Ashgate, p. 27-28.

3 "Therefore, nothing that understanding can understand as different from itself is outside of the subject." R. Petkovšek, Geneza postmoderne misli o Bogu, II., »Tretji dan« (2011) 1/2, p. 9. 
This discussion will show how the, so called, assertive approach in education and economy, attempts to prepare people for the ability to listen to others and be mindful of others' opinions, while also teach them the necessary discipline. ${ }^{4}$ We are interested in testing whether the assertive discipline works in religious education and the Church teaching, which stresses that, "it is necessary for the Church to develop a profoundly religious catechesis, nourished on the Gospel, which will deepen man's encounter with God and forge a bond of permanent communion with Him." ${ }^{5}$ We will show that we need more than assertiveness of the evangelizer for this openness to the Revelation. The anthropological source of human passivity, as understood by P. Ricoeur, will serve as the foundation for openness to others, especially the Other.

\section{An Assertive Method Used in Pedagogy}

The assertive method was born out of necessity, by the teacher Marlene Canter and family counselor Lee Canter, who were facing unteachable children. Through their decades of experience, they encountered children, who had difficulty keeping their responsibilities, and found accepting their parents' or teachers' authority even more difficult. Canter and Canter do not consider discipline, which is a necessity to accept authority, as a means to frighten or punish children. "We define discipline as a corrective action designed to help teach children more appropriate behavior. Under no circumstances should the discipline violate the physical or emotional well-being of the children." ${ }^{6}$ The teaching of discipline is therefore focused on the communication between a teacher and students, as well as parents and children. This does not imply a one-sided communication, in which only the child is obliged to follow certain rules. Above all, it sets

4 "The enthusiasm for a 'new' initiative is a result of the widely held opinion that school discipline has seriously deteriorated and that a number of schools are at breaking point." G. Robinson and B. Maines, Who Manages Pupil Behaviour? Assertive Discipline - A Blunt Instrument for a Fine Task, "Pastoral Care in Education: An International Journal of Personal, Social and Emotional Development" 12 (1994) 3, p. 30.

${ }^{5}$ Congregation for the Clergy, General Directory for Catechesis, http://www.vatican.va/ roman_curia/congregations/cclergy/documents/rc_con_ccatheduc_doc_17041998_directory-for-catechesis_en.html, $\$ 23$.

${ }^{6}$ L. Canter and M. Canter, Assertive Discipline for Parents, New York 2009, Harper Collins, p. 6. 
a clear foundation from which both partners consistently take responsibility during the communicative process. "Assertiveness is the ability to defend your legitimate rights without violating the rights of others. In the process, someone may be hurt, but that should not be the intent. To be assertive is to communicate your concerns, emotions or thoughts as honestly, directly and appropriately as possible."

In a classroom, the teacher is responsible for proper communication. The teacher clearly and firmly communicates his or her needs to the students, and is prepared to reinforce his or her words with appropriate actions. The teacher responds in a manner which maximizes the likelihood of getting the needs met, but in no way violates the best interests of students. It is necessary that the teacher remembers that children need his or her undivided attention, which is the only way for them to learn how to properly listen. Children must feel that the teacher or parent values their positive behavior. Therefore, praise is imperative, because it teaches what kind of behavior is correct, acceptable. In the process, sarcasm must be avoided and eye contact should be kept with children. ${ }^{8}$ Such communication is based on the principle that: teachers have the right to teach, and the right to expect students to behave properly. Only such a presupposition allows us to expect children to take responsibility for their actions and learning. "They learn to follow directions, work on their own, begin and complete a task, manage their time, and work to their full potential."

Students learn to trust and respect an assertive teacher, because they know the teacher is "fair": that he/she means what s/he says and saying what $s /$ he means. Students clearly know the parameters of acceptable and unacceptable behavior. Assertive Discipline is based on a combination of teacher and student rights. But rights are not enough in themselves. They must be developed and formed. The teacher, as the only trained person, must begin the development of proper communication, which will lead from these basic rights to a positive growth process. But teachers must first know themselves. "Assertiveness training encourages educators, especially teachers, to recognize the value of being

${ }^{7}$ L. J. Chamberlin, An Assertive Approach, "American Secondary Education" 12 (1982) 1, p. 2.

8 See L. Canter and M. Canter, Assertive Discipline for Parents, p. 22.

9 L. Canter and L. Hausner, Homework without Tears, New York 2009, Harper Collins, p. 4. 
direct, honest, and no manipulative. In this way teachers control their own communication and can pursue their needs directly."10

Assertive teachers believe that children need positive boundaries, and are prepared to set those boundaries with both words and actions. They back up what they say and enforce rules every time there's an infraction. Assertive responses have two clear components - communication of disapproval followed by a statement of what the child is to do. However, we must remember that every person finds it difficult to change his/her views, or their mind. Thus the assertive approach recommends the broken record technique, ${ }^{11}$ in which the teacher keeps repeating a request to the student without raising their voice or being hurt. ${ }^{12}$ The broken record technique can help teachers remain calm and not fight, argue or debate with students. ${ }^{13}$ Once students realize you won't engage with them, they'll be less likely to continue arguing after the initial statement by the teacher. The Assertive Discipline plan has three main ingredients: a) Teachers should set clear expectations for the behavior they want. b) Concrete and verbal praise and reward for these behaviors. c) A hierarchy of negative consequences for unwanted behaviors.

"A simple technique for the beginner to learn how to be assertive is to simply „say what you want to say when you want to say it." We must also learn to say what we feel. Statements about what you feel or think are just as important as what you want. Purposeful use of the pronoun „I” is one technique for learning to be more assertive. To get started, you might follow the word „I" with „want statement". ${ }^{14}$ We must be careful to allow the children to say "no" when we state our demand for them. Our body language must also support our words, because we cannot be saying one thing, but our body is showing something

${ }^{10}$ L. J. Chamberlin, An Assertive Approach, p. 2.

11 "Make yourself sound like a record that is stuck in a groove. Keep repeating what it is you want - "I want you to do your homework" - no matter what arguments your child puts up." L. Canter and L. Hausner, Homework without Tears, p. 50.

12 "Use a broken record a maximum of three times. If your child still does not do what you want, be prepared to back up your words with actions." L. Canter and M. Canter, Assertive Discipline for Parents, p. 19.

13 "Arguing with your children is a no-win situation. The only result is that everyone gets angry, nothing is solved, and whatever message you're trying to communicate is lost. When you learn to speak so that your children listen, everybody feels better. You feel good because you've calmly stated your expectations, and your children feel better because they know exactly what's expected of them." L. Canter and L. Hausner, Homework without Tears, p. 51.

${ }^{14}$ L. J. Chamberlin, An Assertive Approach, p. 3. 
else. These things muddle the clarity of the assertive communication. When we are assertive, we focus on self-evaluation of a chosen behavior and can easily follow basic personal inclinations, while also follow what we would like to be. With a proper use of assertiveness both the child and the teacher should develop a positive self-image and self-respect, which is a requirement for clear communication and good relationships.

Despite this positive side of assertive discipline, we must admit that too much focus on responsibility and the power of the teacher can be dangerous to the process of education, which tends towards a holistic child development. "The use of Assertive Discipline neglects some of the rights of pupils and parents the right to be listened to, the right to participate in the teaching/learning structure and the right to express needs which may conflict with school or classroom discipline without fear of punishment." ${ }^{15}$ We must also ask ourselves: Do we first need a capable subject for assertive discipline? If a human being is only an instinctive being how could we change this instinctive energy into an acceptable behavior without damaging personal rights? Assertive discipline falls short particularly if we base the learning process on personal trust, and wish to preserve the inner motivation of students to further develop them. L. Canter does not answer the question, how can one allow the child to listen and obey, while also keeping the uniqueness of their personality?

Catechesis must be based on the presupposition that we are all God's children, who carry the mark of uniqueness in us. It must also follow God's pedagogy, which despite complete clarity in the message, accepts people in their brokenness. ${ }^{16}$ We will add Ricoeur's understanding of our triple passivity to assertive discipline, which in itself certainly makes the learning process more organized and productive. Through the help of the anthropological concept, and a constant process of finding one's personality, the teacher's assertiveness

${ }^{15}$ G. Robinson and B. Maines, Who Manages Pupil Behaviour? Assertive Discipline - A Blunt Instrument for a Fine Task, p. 34.

16 "The salvation of the person, which is the ultimate purpose of Revelation, is shown as a fruit of an original and efficacious "pedagogy of God" throughout history. Similar to human usage and according to the cultural categories of time, God in Scripture is seen as a merciful Father, teacher and sage. He assumes the character of the person, the individual and the community according to the conditions in which they are found. He liberates the person from the bonds of evil and attracts him to himself by bonds of love. He causes the person to grow progressively and patiently towards the maturity of a free son, faithful and obedient to his word." Congregation for the Clergy, General Directory for Catechesis, $\$ 139$. 
will find strength in Christian pedagogic and pastoral effort, which follows the revealed truth and the example of Jesus Christ.

\section{Conscience and Passivity in the Philosophy of P. Ricoeur}

A French philosopher, known mostly for his hermeneutic philosophy, towards the end of his work Oneself as Another, in which he contemplates how we become aware of our personality, claims that there are three forms of passivity, which each individual experiences as a constitutive element of self-awareness. If we start thinking about the individual with the notion of personality, which is a closed and autonomous space that Ricoeur calls sameness, but which is also constantly intertwined with the world outside, we must also answer the question: What is the source of the process of thinking about oneself, and what actually caused it? Individuals cannot suddenly step outside themselves, something has to pull them out of the entrapment in their own needs. It is then a constant dialectic between selfhood as ipse-identity, and sameness as what he calls idem-identity.

Ricoeur tries to shed Descartes' self-centered concept of cogito, which is supposed to be the source of modern truth-seeking. He also tackles the complete lack of confidence in the subject itself, as proposed by masters of doubt such as Nietzsche, Marx, and Freud. In his hermeneutic approach, which holds that better understanding requires a better explanation, he accepts the openness of interpretations and sees their conflicts as an opportunity for a better and more useful understanding of a subject. "Ricoeur developed a holistic and integrated understanding of the person as both powerful and vulnerable, finite and infinite, capable and incapable, suffering and acting. In Ricoeur's account, these contrary dimensions stand in tense complementarity without ever reaching a seamless harmony." ${ }^{17}$ Only such definition of our confidence allows us to both respect our inner uniqueness, as well as our ability to learn, which comes from the outside and not just from ourselves, as proposed by J. J. Rousseau. Finding a subject, who feels and therefore understands oneself in the full disparity between greatness and humility ${ }^{18}$ is the ultimate goal of hermeneutic dealing with mankind.

\footnotetext{
17 M. Moyaert, In Response to the Religious Other, Lanham 2014, Lexington Books, p. 31.

18 "He pictures an embodied self with desires that are sometimes frustrated and dreams that clash with the limitations of reality, a self that is inspired by new experiences but also seeks something stable in this ever-changing world, a self that tries to make sense of his life and how it connects to others. Ricoeur's self is a clearly vulnerable creature marked by unchosen
} 
Disparity, in a difficult and never completed interpretation of oneself, is creative. Ricoeur leads to this creative openness through the description of an inner sense of determinism: passivity. Three passivities are a part of our basic understanding of ourselves. "There is the passivity represented by the experience of one's own body - or better, as we shall say later, of the flesh - as the mediator between the self and a world which is itself taken in accordance with its variable degrees of practicability and so of foreignness. Next, we find the passivity implied by the relation of the self to the foreign, in the precise sense of the other (than) self, and so the otherness inherent in the relation of intersubjectivity. Finally, we have the most deeply hidden passivity, that of the relation of the self to itself, which is conscience in the sense of Gewissen rather than of Bewusst." ${ }^{19}$ All three passivities are not something we must choose, they are always already present. Children quickly realize that their bodies do not work the way they wanted them to, which is something we experience throughout our lives. Most developmental psychologists also claim that the principal moment of growing up is the distinction between someone else's will and our own wants. Realization that my own wants may not be other people's wants confronts me with the outside world. Interestingly, Ricoeur classifies conscience as a passivity as well. Freud thought differently, he saw conscience as a product of nurture, which means the other's will. Ricoeur gives it a new dimension, because aside from other's will, he also adds the responsibility of the subject and his or her self-image, as created and desired by themselves. At the same time, conscience is always open to the absolute, which allows us to introduce the religious dimension of education. ${ }^{20}$

The formation of self-awareness happens through language. This is learned and requires constant translating. ${ }^{21}$ The translation of what we hear and read

dimensions, caught up in a finite and often distorted world, and yet is capable of creative transformation and is summoned to responsibility." M. Moyaert, In Response to the Religious Other, p. 31.

19 P. Ricoeur, Oneself as another, Chicago 1992, The University of Chicago Press, p. 318.

20 "The longing for something more, as well as the mention of the call of conscience points to a religious consciousness to which Ricoeur adverts throughout his work-but in occasional essays and never in a sustained way. His care to keep philosophy accessible to the nonreligious is valuable, but it is clear in these essays that he desired his philosophy to be open to the religious direction, thus making it also quite accessible to theology." D. R. Stiver, Ricoeur and Theology, London 2012, Bloomsbury, p. 114.

21 "I am, then, prepared to recognize the historically limited character of my situation and - to return to my comparison with languages - I would say that there is no manner of 
is always an interpretation. Interpretation happens through a dialogue with ourselves, with what we think of ourselves, what we would like to be, and what we feel others want us to be. "In this intimate conversation, the self appears to be called upon and, in this sense, to be affected in a unique way. Unlike the dialogue of the soul with itself, of which Plato speaks, this affection by another voice presents a remarkable dissymmetry, one that can be called vertical, between the agency that calls and the self called upon. It is the vertical nature of the call, equal to its interiority, that creates the enigma of the phenomenon of conscience." 22 The call that we feel in our conscience is what allows us to accept the message of the revelation. In our passivity towards this call of conscience, which we often try to avoid, we unwillingly open ourselves to the process which is supposed to happen in catechesis. It does not deny an individual's will and personality, which we pointed out was a shortcoming of assertive discipline, but includes an openness "to constitute me both as a receptive subject and as a critical subject." ${ }^{23}$ Our starting point, as predicted by Ricoeur, must allow for an openness to more than just the other, which can be defined and understood in our mere human understanding. "Perhaps the philosopher as philosopher has to admit that one does not know and cannot say whether this Other, the source of the injunction, is another person whom I can look in the face or who can stare at me, or my ancestors for whom there is no representation, to so great an extent does my debt to them constitute my very self, or God-living God, absent God-or an empty place. With this aporia of the Other, philosophical discourse comes to an end." ${ }^{24}$

\section{Catechesis on the Road to Emmaus}

The gospel of Luke (Lk 24, 13-33) contains the story of the two disciples who are on their way from Jerusalem to Emmaus. Very disappointed (Ricoeur would

speaking that would lie outside of natural language. The sole resource that we have with respect to this plurality of languages is translation." P. Ricoeur, Critique and conviction: conversations with François Azouvi and Marc de Launay, New York 1995, Columbia University Press, p. 146.

${ }^{22}$ P. Ricoeur, Oneself as another, p. 342.

${ }^{23}$ P. Ricoeur, Critique and conviction: conversations with François Azouvi and Marc de Launay, p. 146.

24 P. Ricoeur, Oneself as another, p. 355. 
say that they are questioning their whole personal identity) they meet a stranger, who apparently has nothing to do with what is on their minds, and what made them abandon their past ideals. This meeting of a stranger, another, Other, which allows them to share their past again, opens their hearts for an inner conversation, which allows for an openness to a revealed truth. If they had walked by themselves and the stranger never met them, they would have sunk in the bitterness of disappointment and built their personality on hurt, and not on the openness to learning. Therefore, the catechist has to be the first to approach a person, respectfully talk to him or her and respect his or her background conscience as it has already been formed before the learning process begun. ${ }^{25}$ This first meeting is only the beginning of a journey which continues through the teaching, or better still explaining, which both of Jesus' sojourners "translate" into their own understanding.

Only such an understanding of learning, which acknowledges the initial disposition of both disciples can lead to real openness to the message. In the end, they both realized, "When he talked with us along the road and explained the Scriptures to us, didn't it warm our hearts?" (Lk 24, 33) The warmth of the heart is this availability and fundamental passivity, a place inside of human consciousness which is ready for learning, and which the Revelation intends to address. Revelation, just as a language, is learned, or passed on, and through it I understand and explain everything surrounding me. ${ }^{26}$ However, I need to accept it and translate it to my own being. At the same time, I only form myself through the acceptance of the Foreign, Other, in Christianity Revealed, just as a child is formed through the learning and usage of language. The disciples are not the same at the beginning and at the end of the journey. And not because Jesus taught them something, but because they allowed him to teach them and embodied what they learned. Jesus, as any catechist should, in his divine catechesis accepts their active role, because he allows them to invite him, and

25 "The catechist knows that it is not enough to have a clear vision for teaching, set goals, content, and formation approach. The relationship is imperative, interpersonal communication, which carries messages, values, and experiences. This is a mutual communication which enriches both the catechist and the student." N. Tunjić, Veroučitelj kot sopotnik veroučencem, "Bogoslovni vestnik", 69 (2009) 4, p. 496.

26 "I would agree to say that a religion is like a language into which one is either born or has been transferred by exile or hospitality; in any event, one feels at home there, which implies a recognition that there are other languages spoken by other people." P. Ricoeur, Critique and conviction: conversations with François Azouvi and Marc de Launay, p. 145. 
at the same time uses the language that is close to them. ${ }^{27}$ This is how we achieve the goal of assertive discipline: the right of the student to learn and the teacher to teach. For a successful initial and long-term growth in Christianity, this disposition has to be implemented in the family, as the primary place of evangelization. ${ }^{28}$

When using assertive discipline and its clarity, which is what Jesus uses on the road to Emmaus, the teacher is in a way a step ahead of the student. The teacher needs to be prepared with a strategy for the teaching process and the methodology that will be used. Jesus does not use this in his teaching. Learning on the Road to Emmaus does not hint to rewards or punishment, which are essential for learning with assertive discipline, where the student needs to clearly know what will happen if he or she listens or does not listen to the teacher. ${ }^{29}$ But Jesus cannot be perceived as lenient either, because his message remains clear and challenging. He explained the entire salvation history and placed in it in the event of his suffering and resurrection. This is not the authority of the teacher, but the authority of the truth, which speaks to the frightened disciples. Assertiveness, which justifiably stresses the authority of the teacher, and the difficulty of the learning process, is only possible when we accept the dignity of the student and his or her somewhat formed self-image, or as Ricoeur puts it, we are using the mother tongue, into which every new thought is translated. Accepting the dignity of the student means that the student must feel that as well. The student's passivity cannot be addressed with aggression and despise, but with love and respect. Only then will he or she be attentive to the needs of others. This is a clear assertive stance, upon which the Church teaching will be founded, which gives parents, as the primary teachers this responsibility: "In a society shaken and split by tensions and conflicts caused by the violent clash of various kinds of individualism and selfishness, children must be enriched not only with a sense of true justice, which alone leads to respect for the personal dignity of each individual, but also and more powerfully by a sense of true love,

${ }^{27}$ See E. Osewska, Erwartunge an die katholische Schule in einem postmodernen Zeitalter, "The Person and the Challenges" 1 (2011) 2, p. 102.

${ }^{28}$ See J. Stala, Der Mensch als Person: Die bestimmende Grundlage für Johannes Paul II. in seinem Bild von der Famille, "The Person and the Challenges" 2 (2012) 2, p. 46.

29 "Once the programme is in place the teacher bears the full responsibility for all three elements whilst the student 'chooses' the rewards or the punishments." G. Robinson and B. Maines, Who Manages Pupil Behaviour? Assertive Discipline - A Blunt Instrument for a Fine Task, p. 31. 
understood as sincere solicitude and disinterested service with regard to others, especially the poorest and those in most need." ${ }^{30}$

While the disciples fully recognized the truth only after they had invited Jesus to stay with them, they were led by their longing for the truth throughout the journey. Because Jesus spoke to them correctly and they felt the teacher's clear point, this realization leads them from being closed off to now caring for others' needs - to start sharing their story. They returned to the community from which they had been fleeing and shared their new knowledge with them. The message did not just increase their knowledge, it also influenced their actions. Conscience, as understood by Ricoeur, connects the openness to the call of the Other, God, as well as the openness to a new life in a community in which we grow and learn. This is a process that includes both students and a teacher. The divine dignity of each student, which is bestowed upon us through creation and adoption through Jesus Christ, should be the realm of any Christian education, because only that leads to a community of believers. This honors both God's and the catechist's assertiveness. Jesus is clear in his remark that the disciples are slow to believe. But he does not leave them on their journey, he waits patiently for the moment when they are able to accept the new outlook in the disparity of the dialogue. The roles must be clearly defined. If the disciples are to be freed from the disappointment and accept the message, they must stay true to themselves, in this case to the fear and disappointment, which had taken them from Jerusalem. If Jesus is to bring newness to their state, he must remain true to himself and his Otherness. Ricoeur can only help us ask, "In short, is it not necessary that a dialogue superpose a relation on the supposedly absolute distance between the separate I and the teaching Other?"31 The Assertive method states the clear division between the participants in the learning process, but at the same time neglects the same power of the pre-formed personalities of the student and the teacher. Knowledge is not what makes the teacher superior to the students, which is especially true in catechesis. It is an inner disposition, a conversion, a decision for a new outlook of ourselves, the world around us, our entire being. To achieve that we need the holistic personalities of both the teacher and the student. In achieving that, we will follow John Paull II, who says, "If conceived in this way, catechesis goes beyond every form of formalistic moralism, although

${ }^{30}$ John Paul II, Familiaris Consortio, http://w2.vatican.va/content/john-paul-ii/en/apost_ exhortations/documents/hf_jp-ii_exh_19811122_familiaris-consortio.html, $₫ 37$.

31 P. Ricoeur, Oneself as another, p. 339. 
it will include true Christian moral teaching. Chiefly, it goes beyond any kind of temporal, social or political „messianism.” It seeks to arrive at man's innermost being." ${ }^{2}$

\section{Conclusion}

We started our discussion with the difficulty of upbringing and education today and proposed assertive discipline as a possible solution, but it proved to insufficiently consider our divine childhood. Ricoeur's hermeneutical path to building up consciousness about ourselves allowed us to combine the difficulties of assertiveness and respect for individuals during the learning process. We, therefore, showed that it is possible to meet the expectations that the Church has for catechists and the process of catechesis, "As a good mother she gives them the Gospel in all its authenticity and purity as apposite food, culturally enriched and a response to the deepest aspirations of the human heart." ${ }^{33}$ The human heart, if understood as Ricoeur's conscience, is the outlook which presupposes Otherness, or nowadays mostly foreignness of the message. To many people, this foreignness, otherness, means something bad, because it is difficult to connect to our everyday lives. Despite the Church's attempt to enculturate evangelization, it is good that we keep the authenticity of the message. That way we overcome the danger which was pointed out at the beginning, that we would only repeat what is already present within us.

By accepting that we are influenced by passivity, we allow ourselves to be sensitive to something outside of ourselves, and at the same time, show the fruitfulness of this often burdensome tension between own and foreign. The dynamic process of developing our own personality enables evangelization, in which divine will not be forgotten, but will enrich and challenge the modern man. Just as the disciples on the road to Emmaus would never have had their eyes opened without a true readiness, compassion for the stranger who approaches them on the way, our eyes also cannot be opened unless we start from this primary readiness, as shown by the concept of triple passivity. But without Jesus' clear, assertive disposition, the road to Emmaus would have ended in

${ }^{32}$ John Paul II, Catechesi tradendae, http://w2.vatican.va/content/john-paul-ii/en/apost_ exhortations/documents/hf_jp-ii_exh_16101979_catechesi-tradendae.html, $₫ 52$.

${ }^{33}$ Congregation for the Clergy, General Directory for Catechesis, $\$ 79$. 
complaining about the cruelty of life. Catechesis must follow people wherever and whoever they are. At the same time, however, it must be true to the Revealed curriculum, because it can only then bring people from passivity which tires us, to a passivity which calls us to the fullness of life.

\section{Bibliography}

Canter L. and Canter M., Assertive Discipline for Parents, New York 2009, HarperCollins. Canter L. and Hausner L., Homework without Tears, New York... 2009, HarperCollins. Chamberlin L. J., An Assertive Approach, “American Secondary Education” 12 (1982) 1, p. $2-4$.

Congregation for the Clergy, General Directory for Catechesis, http://www.vatican.va/ roman_curia/congregations/cclergy/documents/rc_con_ccatheduc_doc_17041998_ directory-for-catechesis_en.html (16.05.2017).

John Paul II, Catechesi tradendae, http://w2.vatican.va/content/john-paul-ii/en/apost_ exhortations/documents/hf_jp-ii_exh_16101979_catechesi-tradendae.html (14.05.2017)

John Paul II, Familiaris Consortio, http://w2.vatican.va/content/john-paul-ii/en/ apost_exhortations/documents/hf_jp-ii_exh_19811122_familiaris-consortio.html (15.05.2017)

Lantieri L. ed., Schools with Spirit. Nurturing the Inner Lives of Children and Teachers, Boston 2001, Beacon Press.

Moyaert M., In Response to the Religious Other, Lanham 2014, Lexington Books.

Osewska E., Erwartunge an die katholische Schule in einem postmodernen Zeitalter, „The Person and the Challenges" 1 (2011) 2, p. 95-108.

Petkovšek R., Geneza postmoderne misli o Bogu, II., »Tretji dan« (2011) 1/2, p. 5-15.

Ricoeur P., Oneself as Another, Chicago 1992, The University of Chicago Press.

Ricoeur P., Critique and conviction: conversations with François Azouvi and Marc de Launay, New York 1995, Columbia University Press.

Robinson G. and Maines B., Who Manages Pupil Behaviour? Assertive Discipline - A Blunt Instrument for a Fine Task, "Pastoral Care in Education: An International Journal of Personal, Social and Emotional Development” 12 (1994) 3, p. 30-35.

Stala J., Der Mensch als Person: Die bestimmende Grundlage für Johannes Paul II. in seinem Bild von der Famille, „The Person and the Challenges“ 2 (2012) 2, p. 41-59.

Stiver D. R., Ricoeur and Theology, London 2012, Bloomsbury.

Topping R. R., Revelation, scripture and church: theological hermeneutic thought of James Barr, Paul Ricoeur and Hans Frei, Burlington, Aldershot 2007, Ashgate.

Tunjić N., Veroučitelj kot sopotnik veroučencem, "Bogoslovni vestnik« 69 (2009) 4, p. 493-507. 